MIRJANA VOJVODA

Archaeological Institute

Belgrade, Serbia

E-mail: mirjana.vojvoda@gmail.com

SAŠA REDŽIĆ

Archaeological Institute

Belgrade, Serbia

E-mail: sasa.redzic@gmail.com
Received: August $07^{\text {th }} 2020$

Accepted: December $10^{\text {th }} 2020$

Original research article

904:726.821"652"(497.11)

904:737.1.032(37)"00/02"

COBISS.SR-ID 29127945

https://doi.org/10.18485/arhe_apn.2020.16.7

\title{
INCIDENCE OF DENOMINATIONS IN GRAVES AT THE SOUTHERN NECROPOLISES OF VIMINACIUM
}

\begin{abstract}
At the southern necropolises of Viminacium, coins as grave goods were recorded in $24.60 \%$ of the total number of discovered graves (10769). These data show a discrepancy between the ancient source reports about the use of so-called "Charon's obol" and archaeological evidence. Even though only about a fourth of the graves contain coins as grave goods, this percentage is above the average reported on analogous necropolises in the surrounding area. From this number, the incidence of asses and dupondii is by far the most frequent, thus confirming the use of low-value denominations in funeral practice. It may be also concluded that in the largest percentage, the custom of placing the coin in the mouth of the deceased was observed, especially in the example of graves with one coin.
\end{abstract}

\section{KEYWORDS: ROMAN EMPIRE, NECROPOLISES, COINS, DENOMINATIONS, VIMINACIUM.}

Roman beliefs about the afterlife were diverse, and investigations of necropolises across the former Empire provide some guidelines on which to base conclusions. However, it is still very difficult to assess what and (to what extent) people believed in, as well as how their beliefs were developing and changing through time, bearing in mind some perceived distinctions that varied in different parts of the Empire ${ }^{1}$. In an attempt to illuminate to a degree the nature of funerary customs practised at the Viminacium southern necropolises, primarily from the aspect of the use of coins, we have analysed the types of denominations which were deposited in the graves.

At the Viminacium southern necropolises (Više Grobalja and Pećine), from the $1^{\text {st }}$ to the

1 More recent research highlights regional differences in funerary rituals, but also confirms some similarities: forms of burial (cremation and inhumation), parallel existence of both rituals, gradual transition to inhumation, burials outside the city walls, etc.; cf. Hope 2007: 129. mid- $3^{\text {rd }}$ centuries, both cremation and inhumation rites were practised. In the mid-3rd century, the ritual of cremation of the deceased was abandoned and the only burial type from that moment on was inhumation. During rescue archaeological investigations in this area from 1978 to 1990, a total of 10769 graves were discovered, of which 2930 were cremation burials and 7839 inhumation burials (Table 1). From the total number of recorded graves, only 2649 contained coins as grave goods, which is $24.60 \% .^{2}$ Coins are were

2 Viminacium: Vojvoda i Mrđić 2015: 12, Table 3; Vojvoda i Mrđić 2017: 12, Table 3; Brigetio: 20.16\% (average of three necropolises where the percentages from 19.54 to $29.46 \%$ were recorded), cf. Găzdac-Alföldy and Găzdac 2009: 162, Fig. I; Matrica: 21.50\%, cf. Topal 1981: 95; Emona: 14.40\%, cf. Petru 1972; Plesničar-Gec 1972; Miškec 2012: 135; Novaesium approximately $14 \%$ and Gerulata only 6\%, cf. Topal 1981: 95, ref 276; Ptuj (western necropolises): $18.17 \%$, cf. Istenič 2000: 14-259; Singidunum: 12.59\%, cf. Simić 1997: 46; Pop-Lazić 2002: 19-39. The data from the last two necropolises should be taken with some reservations due, to the deficient and am- 


\begin{tabular}{|l|c|c|c|}
\hline & $\begin{array}{c}\text { Number of } \\
\text { graves }\end{array}$ & $\begin{array}{c}\text { Number of } \\
\text { graves with the } \\
\text { coins }\end{array}$ & $\%$ \\
\hline Inhumations & 7839 & 1461 & 18.65 \\
\hline Cremations & 2930 & 1188 & 40.55 \\
\hline Total & 10769 & 2649 & 24.60 \\
\hline
\end{tabular}

Table 1 - Incidence of graves with coins as grave goods

much more present in cremated burials $(40.55 \%)$ then in inhumation burials (18.65\%).

Already, these data clearly show a certain discrepancy between the ancient source reports and the real role that coins had in funerary rituals at the Viminacium necropolises. Greek and Latin sources from the $5^{\text {th }}$ century $\mathrm{BC}$ to the $2^{\text {nd }}$ century $\mathrm{AD}$, regardless of certain differences in their accounts, make reference to the custom of placing a single low-value coin into the mouth of the deceased immediately after death, as a tax for their transportation across the Acheron or Styx to the underworld (Stivens 1991: 215). The custom originates from the belief that it was necessary to pay Charon for the transition to the world of the dead. Initially from the Mediterranean cultural circle, at the time of the Roman Empire this custom had spread to biguous documentation from earlier excavations, which subsequent researchers encountered in the process of publishing the necropolises. the north-western provinces (Toynbee 1971: 49). The necessity of placing the so called "Charon's obol" into the mouth of the deceased, with the intention for it to touch the soul, closely relates to the time of placing the coin. It was inserted at the time of death when, as it was believed, the soul began its journey to the other world. This fact is crucial for understanding the custom, as the placement of the coin signifies the ritual of transition, closing the passage between the living and the dead, rather than the practice during burial (Stivens 1991: 221). Coin finds from numerous investigated necropolises across the Empire, including those of Viminacium, confirm the occasional use of low-value denominations in funerary practice. What surprises us is the discrepancy between the reports from ancient sources and the archaeological evidence - the facts that only a small number of graves contained coins, that sometimes a num-

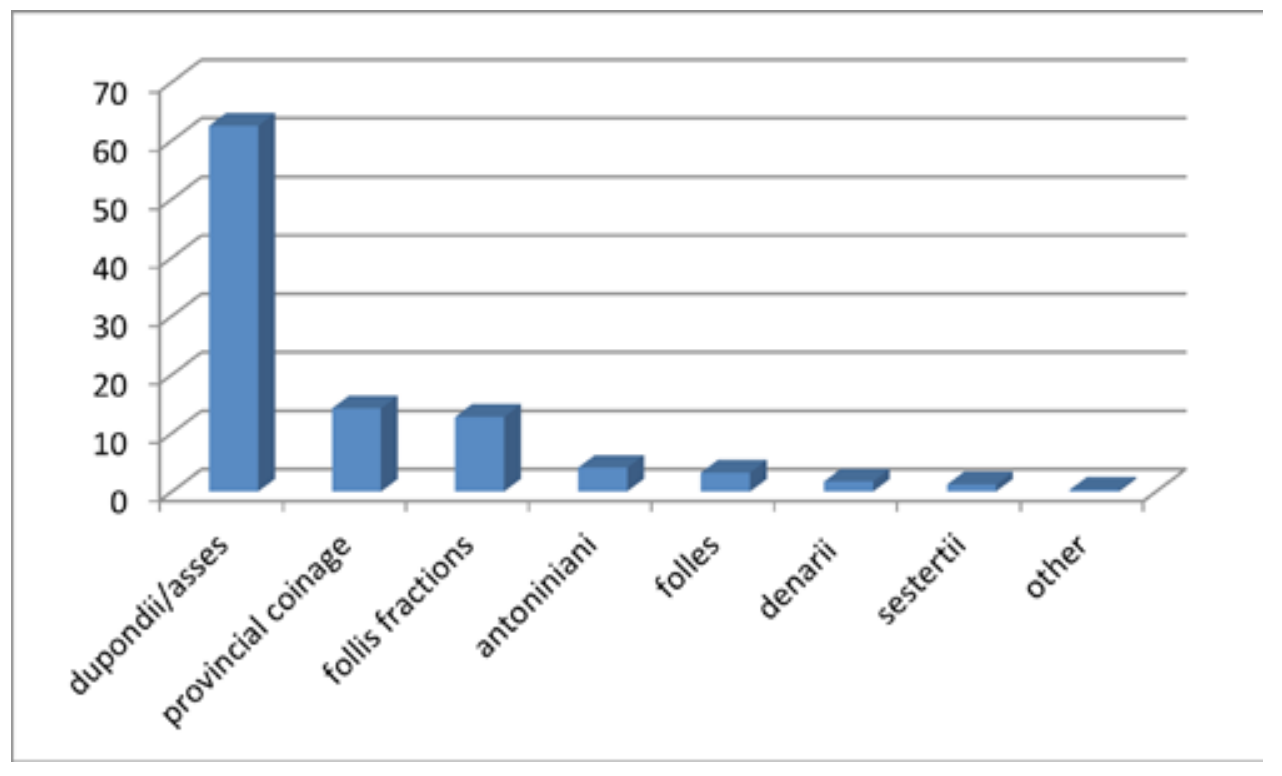

Graph 1 - Incidence of denominations at the Viminacium southern necropolises graves 
ber of coins occured, and that they were placed on different parts of the body or around it.

As already noted, in only about one fourth of the graves at Viminacium southern necropolises, coins as grave goods were recorded $(24.60 \%)$. The fact is that among this fourth, a single low-value coin was recorded in the largest percentage $(86.20 \%) .{ }^{3}$ A large discrepancy in relation to the ancient sources is also reflected in the location of the coin finds within inhumation burials. Only $28.40 \%$ of coins were placed in the mouth of the deceased, while an additional $20.70 \%$ were found around the head of the deceased. In a notable percentage, other coins were recorded on the torso $(10.70 \%)$, followed by the pelvic region $(6.70 \%)$, while other positions (next to legs or feet, or next to arms) were recorded in a small percentage. In graves with two coins in their inventory $(9.80 \%)$, different combinations of placement were noted, with the largest percentage recorded in the mouth and around the head (together $32.20 \%$ ). In a few graves with a larger number of coins (from 4 to 88 ) in which it was possible to determine their position, they were mostly found next to the feet, legs, or the pelvis.

Depositing low-value coins in the graves is in accordance with the claims of the ancient sources. The most prevalent coins are dupondii and asses $(62.50 \%)$, followed by the provincial editions (14.20\%), follis fractions $(12.74 \%)$, antoniniani (4.07\%), and denarii (1.72\%), while the incidence of sestertii is only $1.20 \%$ (Graph 1). Observed by century, the presence of silver coins in graves increases with the decrease of their real value from the 1 st century ( $13 \mathrm{pcs}$.) through the $2 \mathrm{nd}$ ( $40 \mathrm{pcs}$.), to the 3 rd century ( 96 pcs.). The exceptions are the finding of three solidi and one semis of Valentinian I in a grave of an individual interred without a coffin, ${ }^{4}$ as well as a newly found hoard of

3 Graves with two coins are represented with $9.80 \%$, followed by the graves with three coins $(1.91 \%)$, while other occurrences (from 4 to the hoards with 88 coins) are present in small percentage.

4 Pećine necropolis, G-5571, an individual interred without a coffin, laid on the back, with the arms crossed on the
7 solidi (Honorius - Theodosius II) in one of the monumental tombs. ${ }^{5}$

Concerning the most numerous denominations from graves, dupondii and asses, these are mostly examples with traces of long-term usage before depositing. This particularly refers to the samples emitted during the $1^{\text {st }}$ century, which make up $15.56 \%$ of the coins in the graves. ${ }^{6}$ From the analysis of graves with several coins, of which at least one is from the $1^{\text {st }}$ century, it has been noticed that the largest number of these graves are dated to the $2^{\text {nd }}$ or even $3^{\text {rd }}$ century. This suggests the need for ultimate caution when dating the graves with one coin from the 1st century as grave goods, and that in these cases, an additional 60-120 years should be taken in account, at least when it comes to the Viminacium southern necropolises. A greater presence of provincial emissions in the graves refers mostly to the $3^{\text {rd }}$ century issues, primarily from the Nicaean mint, whose presence testifies to the deficiency of small bronze coins in circulation, which was pronounced in Upper Moesia starting from the reign of Caracalla to the reign of Gordian III.

Based on the above, it can be concluded that the custom of placing coins in the grave was respected by only a part of the population at Viminacium and was more firmly rooted in the section of the population that practised cremation. Within one quarter of the graves containing coins, it can be said that the custom of placing coins in the mouth of the deceased was honoured in the largest percentage of cases, particularly in graves with a single coin. In general, low-value coins with traces of longer use were deposited.

pelvis.. After lifting the skeleton, under the left half of the pelvis, four gold coins of Valentinian I were discovered. (field inv. C - 13391-13394). These were the only grave goods in the grave (cf. fieldwork diary, 3761, 3763). These gold coins unfortunately disappeared during the robbery of the National Museum in Požarevac.

5 Pećine necropolis, G-5868, discovered in 2016. g.; cf. Vojvoda and Redžić 2020: 217-231.

6 The 2nd century issues are present in the largest percentage $(43.54 \%)$, followed by the 3 rd century emissions $(26.27 \%)$, 1st century, then 4 th $(14.45 \%)$ and finally 5 th century $(0.18 \%)$. 


\section{BIBLIOGRAPHY}

Găzdac-Alföldy, Á. and Găzdac, C. 2009

Coins in Funerary Contexts. The Case of Brigetio, In: Ex Officina... Studia in honorem Dénes Gabler, Ed. B. Szilvia:161-173, Győr: Mursella.

\section{Hope, V. M. 2007}

Death in Ancient Rome, London \& New York: Routledge.

Istenič, J. 1999

Petovio, zahodna grobišča II, Grobne celote iz Deželnega muzeja Joanneuma v Gradcu, Ljubljana 1999: Narodni muzej Slovenije.

Miškec, A. 2012

The analysis of monetary finds from the graves of Emona's cementeries, In: Emona: med Akvilejo in Panonijo / between Aquileia and Pannonia, Eds. I. Lazar, B. Županek: 133-141, Koper: Univerza na Primorskem.

Petru, S. 1972

Emonske nekropole (odkrite med leti 1635-1960), Ljubljana: Narodni muzej Slovenije.

\section{Plesničar-Gec, Lj. 1972}

Severno emonsko grobišče, Ljubljana: Mestni muzej.

\section{Pop-Lazić, S. 2002}

Nekropole rimskog Singidunuma, Singidunum 3: 7-100.

\section{Simić, Z. 1997}

Rezultati zaštitnih arheoloških istraživanja na prostoru jugoistočnenekropole Singidunuma, Singidunum 1: 21-56.

Stivens, S. T. 1991

Charon's Obol and other Coins in Ancient Funerary Practice, Phoenix, Vol. 45.3: 215-229.

\section{Topál, J. 1981}

The Southern Cemetery of Matrica (Százhalombatta-Dunafüred), Budapest: Akadèmiai Kiadò.

Toynbee, J. M. C. 1971

Death and Burial in the Roman World, London: Thames and Hudson.

Vojvoda, M. and Mrđić, N. 2015

Coin finds from the Viminacium necropolis of Više grobalja and their role in funerary ritual/Nalazi novca sa viminacijumske nekropole Više grobalja i njihova uloga u pogrebnom ritualu, Belgrade 2015: Institute of Archaeology.

Vojvoda, M. and Mrđić, N. 2017

Coin finds from the Viminacium necropolis of Pecine and their role in funerary ritual/Nalazi novca sa viminacijumske nekropole Pećine i njihova uloga u pogrebnom ritualu, Belgrade 2017: Institute of Archaeology.

Vojvoda, M. and Redžić, S. 2020

A hoard of solidi from a hypogeum at the Viminacium necropolis of Pećine, Arheološki vestnik 71: 217-231.

\section{REZIME \\ ZASTUPLJENOST NOMINALA U GROBOVIMA NA VIMINACIJUMSKIM JUŽNIM NEKROPOLAMA}

\section{KLJUČNE REČI: RIMSKO CARSTVO, NEKRO- POLE, NOVAC, NOMINALI, VIMINACIJUM.}

$\mathrm{Na}$ viminacijumskim južnim nekropolama (Više Grobalja i Pećine) istovremeno su upražnjavani rituali kremacije i inhumacije od 1 . do sredine 3. veka. U to vreme obred kremacije pokojnika bio je napušten i jedini vid sahranjivanja nadalje predstavlja inhumacija. Tokom zaštitnih arheoloških istraživanja od 1978. do 1990. go- 
dine u ovom arealu otkriveno je ukupno 10769 grobova kremiranih (2930) i inhumiranih (7839) pokojnika (Tabela 1). Od ukupnog broja registrovanih grobova samo 2649 njih sadržavalo je novac kao prilog, što iznosi $24,60 \%$. Pri tome novac je znatno više prisutan $u$ grobovima kremiranih $(40,55 \%)$ nego u grobovima inhumiranih pokojnika $(18,65 \%)$.

Kod ove četvrtine grobova, u najvećem procentu registrovano prisustvo jednog novčića $(86,20 \%)$ male vrednosti. U najvećoj meri prisutni su dupondijusi i asi $(62,50 \%)$, slede provincijska izdanja $(14,20 \%)$, frakcije folisa $(12,74 \%)$, antoninijani $(4,07 \%)$, denari $(1,72 \%)$, dok su sestercijusi prisutni samo sa 1,20\% (Grafikon 1).

Običaj prilaganja novca u grob bio poštovan samo od dela populacije na Viminacijumu i čvršće je bio ukorenjen u delu populacije koji je praktikovao kremaciju. U okviru četvrtine grobova koja je sadržavala novac, može se reći da je u na- jvećem procentu poštovan običaj stavljanja novca u usta pokojnika naročito u primeru grobova sa jednim novcem. Prilagani su uglavnom novčići male vrednosti sa tragovima dužeg korišćenja.

Arheologija i prirodne nauke (Archaeology
and Science) is an Open Access Journal. All ar-
ticles can be downloaded free of charge and used
in accordance with the licence Creative Com-
mons - Attribution-NonCommercial-NoDerivs
3.0 Serbia (https://creativecommons.org/licenses/
by-nc-nd/3.0/rs/.
Časopis Arheologija i prirodne nauke je dos-
tupan u režimu otvorenog pristupa. Članci ob-
javljeni u časopisu mogu se besplatno preuzeti
sa sajta i koristiti u skladu sa licencom Creative
Commons - Autorstvo-Nekomercijalno-Bez
prerada 3.0 Srbija (https://creativecommons.org/
licenses/by-nc-nd/3.0/rs/.

